\title{
Relations between the Perception of Communication Difficulties, Stress Levels and Behavior of Children with Autism Spectrum Disorders
}

\section{Juliana Izidro Balestro, Cibelle Albuquerque de la Higuera Amato, Vanessa Sugawara, Isabela Gibello, Letícia Segeren, Fernanda Dreux M. Fernandes}

Universidade de Sao Paulo, Sao Paulo, Brazil

Email: jubalestro@hotmail.com

How to cite this paper: Balestro, J. I., de la Higuera Amato, C. A., Sugawara, V., Gibello, I., Segeren, L., \& Fernandes, F. D. M. (2016). Relations between the Perception of Communication Difficulties, Stress Levels and Behavior of Children with Autism Spectrum Disorders. Psychology, 7, 13911396.

http://dx.doi.org/10.4236/psych.2016.712139

Received: July 27, 2016

Accepted: October 31, 2016

Published: November 3, 2016

Copyright $\odot 2016$ by authors and Scientific Research Publishing Inc.

This work is licensed under the Creative Commons Attribution International License (CC BY 4.0).

http://creativecommons.org/licenses/by/4.0/

\section{Abstract}

The way that children are perceived by their families interferes with their experiences in society demanding that the parents' perspectives are taken into account. The aim of this study was to identify the association among the autism symptoms reported by the parents of children with ASD, their perception of communication difficulties and the stress level reported by them. Participants were the parents of 19 children with ASD. They answered three questionnaires: the Autism Behavior Checklist, one questionnaire about their difficulties in communicating with their child and another about their stress level. Each domain of each questionnaire was correlated with all items of the other two. The results indicated that there was no association among the answers. These results suggest what parents of children with ASD perceive as difficulties when communicating with their child and their stress level is not associated with the severity of the symptoms they identify in their child. The parents' perceptions about subjective issues of life reflect on how they cope with the specific needs of their children.

\section{Keywords}

Autistic Disorder, Communication, Social Behavior, Stress, Family

\section{Introduction}

Autism Spectrum Disorders (ASD) are characterized as a behavioral syndrome of multiple etiologies, which compromises the child's developmental process (APA, 2002; 
OMS, 2000). This syndrome affects social interaction, communication and general behavior of the child, resulting in restricted interest and stereotyped and repetitive activities. To identify and characterize children with ASD, many tools are used, including the Autism Behavior Checklist (ABC), which is comprised of a non-adaptive behavior checklist that is part of the Autism Screening Instrument for Educational Planning (ASIEP) (Marteleto \& Pedromônico, 2005) and created to screen and indicate likelihood of diagnosis of autism, which allows a detailed description of the atypical behavior that is characteristic to each individual (Marteleto \& Pedromônico, 2005; Tamanaha, Marteleto, \& Perissinoto, 2014). Other studies suggest that the symptoms of ASD trigger high levels of stress in family members (Allen, Bowles, \& Weber, 2013; Sivberg, 2002). Parents of children with ASD report going through periods of stress mainly due to the child's difficulties in communication, behavior, social involvement in activities of daily living and the lack of understanding by the community (Balestro \& Fernandes, 2012; Segeren \& Françozo, 2014). One of the potential stress factors cited by parents is the difficulty of communication, and the impairments in this area include the difficulties of the child to make him/herself understood by others, and problems in socialization and language.

Autism spectrum disorders are a complex behavioral syndrome. It impairs the development throughout life and has great variability in symptoms and intensity in the various areas that define the diagnosis (Schmidt \& Bosa, 2003). Persons with autism need special care during all life and therefore the caretakers also need attention. Parental stress in families with children with autism is significantly higher than the observed in families with children with other disorders or with typical development (Hayes \& Watson, 2013). Communication is specially affected in autism, it is one of the parent's first concerns and may increase stress levels. Studying the impact of speech in the stress level of parents of children with ASD may provide useful insights to the intervention planning. Therefore, this study asked if parents of non-verbal children with autism had higher levels of stress than parents of verbal children with autism and aimed to identify the association between the autism symptoms reported by them and their perception of communication difficulties (Andrade \& Teodoro, 2012; Artigas-Pallarés, 1999).

\section{Objectives}

The aim of this study was to identify the association among the autism symptoms reported by the parents, their perception of communication difficulties and the stress level reported by them.

\section{Methods}

\subsection{Participants}

Participants were 19 parents of 19 children with ASD, of both genders, aged between 27 and 54 years and 11 months, which responded to the questionnaires. The children in this study aged between 4 and 15 years old. Other demographic data were not considered. They all signed the consent form approved by the institution's research committee. 


\subsection{Instruments}

The tools used were the $\mathrm{ABC}$, a stress protocol and a questionnaire about parents' difficulties in communicating with their child (Marteleto \& Pedromônico, 2005; Balestro \& Fernandes, 2012; Segeren, 2015).

The $\mathrm{ABC}$ is a questionnaire that refers to five areas of development: Sensory, Relationship, Use of body and objects, language and personal and social development (ES, RE, CO, LG and PS), which has balanced score (1 - 4) according to the occurrence in ASD. From the sum of the scores, it draws up a behavioral profile that allows the analysis of probability for the ASD diagnosis. It is a tool used to identify the risk, or the probability of a diagnosis within the autism spectrum. A score between 47 and 53 indicates a low probability; moderate risk is associated with total scores between 54 and 67, and scores from 68 up indicate a high probability of the child being diagnosed as with autism. It has been used in previous studies (Marteleto \& Pedromônico, 2005; Tamanaha, Marteleto, \& Perissinoto, 2014).

Both the stress protocol and the questionnaire about communication difficulties are divided into different domains. The questionnaire about communication difficulties (Balestro \& Fernandes, 2012) has four domains: the first domain involves the parents' impression about themselves in relation to their children (D1); the second refers to their perception regarding the acceptance of their children by other people (D2); the third focus on the attitude of parents regarding their children (D3) and the fourth concerns the parents' impressions about their children (D4).

The stress protocol has 39 questions divided in three domains: family, physical symptoms and the child. Questions refer to the participant's family and their feelings regarding themselves. Participants should answer if the feelings were always, frequently, rarely or never true (Likert scale). The answers result on a score and the stress level is accordingly classified: scores equal or under 20-no apparent stress; scores between 21 and 46: medium level of stress; scores at or above 47 high stress level.

\subsection{Data Analysis}

Fisher's Exact test was carried out for testing the association between each questionnaire domain and both the $\mathrm{ABC}$ and the stress protocols separately. The statistical analysis was performed using the SPSS ${ }^{\circledR}$ 18.0.0 package. This test was used in its twotailed mode, wherefore, $p$-values $<0.05$ were considered for statistical significance.

\section{Results}

There were no correlations between the three protocols, which suggest that the stress reported by parents is not directly related to the severity of the symptoms or communication difficulties they perceive in their child. Results regarding parents' perception are displayed in Table 1 and Table 2.

\section{Discussion}

The child's severity of behavior disorders and other symptoms apparently do not reflect 
Table 1. Association between each domain of the communication difficulties questionnaire and the $\mathrm{ABC}$ and stress protocols.

\begin{tabular}{ccc}
\hline Variables & Fisher's Exact Test & $P$-value \\
\hline ABC protocol & & \\
D1 & 3.143 & 0.632 \\
D2 & 4.762 & 0.391 \\
D3 & 3.800 & 0.512 \\
D4 & 5.587 & 0.240 \\
\hline
\end{tabular}

Table 2. Association between each domain of the communication difficulties questionnaire and stress protocols.

\begin{tabular}{ccc}
\hline Variables & Fisher's Exact Test & $P$-value \\
\hline Stress protocol & & \\
D1 & 2.416 & 0.386 \\
D2 & 3.347 & 0.225 \\
D3 & 2.522 & 0.296 \\
D4 & 1.184 & 0.625 \\
\hline
\end{tabular}

the actual experiences of the families. The way by which difficulties and symptoms are interpreted and the meaning associated to them seems to be what determines this representation (Balestro \& Fernandes, 2012). It can be supposed that the stress levels are associated to the way these difficulties are perceived by the parents, thus showing their subjective responses. Other studies (Balestro \& Fernandes, 2012; Sperry \& Symons, 2003) have shown that the representation of parents is related to factors such as the social support they receive, acceptance of people, independence, flexibility and resilience.

The ways children are perceived by their families interfere with their experiences in society, considering that language and socialization interfere mutually during communicative exchanges. Therefore, it is essential to take into account the familiar perspective about the communication disorders and their impact in the family's life and that's why each case must be analyzed and addressed individually. When data were pooled, there were no significant statistical differences, given the form parents perceive the difficulties of their children and how they deal with them. However, when these data are analyzed separately they provide important information about the family context in which the child is growing and the specific coping mechanisms.

Apparently, the caregiver's profile determines their perception of each child's difficulties and interferes in the communicative process. It leads to the valorization or to the depreciation of the dyadic interaction (Sperry \& Symons, 2003; Cia, Pereira, Del Prette, \& Del Prette, 2006).

The perception of parents about the stigma of the disorder also seems to have an important role in the social and functional adaptation of both parents and children 
(Balestro \& Fernandes, 2012; Hayes \& Watson, 2013; Duarte, Bordin, Yazigi, \& Mooney, 2005).

Other research concluded that the stigma is reinforced by society and its effects are nor easily overcome (McStay et al., 2013; Rivard, Terroux, Parent-Boursier, \& Mercier, 2014). The family's social relations are damaged, and the members go through a period of stress usually generated by the low acceptance of autistic behaviors by society and by other family members, as well as lack of social support (McStay et al., 2013). This means that the lack of social support and stigma are aspects with which families have necessarily to cope. However, it does not mean that this issue can be addressed without any difficulty.

Knowing and considering the parents' perception about their child with autism is useful in planning and designing guidelines that are useful to them and their individual needs.

\section{Limitations and Future Research}

The sample size of this study was small. Future controlled studies using larger samples and with different parents' profile (e.g., social economic levels, parents and services providers, parent's occupation...) can better explore the difficulties in coping by parents of children with ASD.

\section{Conclusions}

The absence of association shows that the perception of parents is variable and is not directly related to the difficulties presented by the children, but with subjective responses and the way they cope with them.

These findings are clinically important to help each family develop their own strategies for understanding and adapting to its consistent reality, their life style and values.

\section{References}

Allen, K. A., Bowles, T. V., \& Weber, L. L. (2013). Mothers' and Fathers' Stress Associated with Parenting a Child with Autism spectrum Disorder. Autism Insights, 5.

American Psychiatric Association (APA) (2002). Manual de diagnóstico e estatística de distúrbios mentais (DSM-IV-TR) (4a ed.). Porto Alegre: Artmed.

Andrade, A. A., \& Teodoro, M. L. M. (2012). Família e Autismo: Uma Revisão da Literatura. Contextos Clínicos, 5, 133-142.

Artigas-Pallarés, J. (1999). El lenguaje en los trastornos autistas. Revista de Neurologia, 28, S118-S123.

Balestro, J. I., \& Fernandes, F. D. M. (2012). Questionário sobre dificuldades comunicativas percebidas por pais de crianças do espectro do autismo. Revista da Sociedade Brasileira de Fonoaudiologia, 17, 279-286. http://dx.doi.org/10.1590/s1516-80342012000300008

Cia, F., Pereira, S. C., Del Prette, Z. A. P., \& Del Prette, A. (2006). Habilidades sociais parentais e o relacionamento entre pais e filhos. Psicologia em Estudo, Maringá, 11, 73-81.

Duarte, C. S., Bordin, I. A., Yazigi, L., \& Mooney, J. (2005). Factors Associated with Stress in Mothers of Children with Autism. Autism, 9, 416-427. 
http://dx.doi.org/10.1177/1362361305056081

Hayes, S. A., \& Watson, S. L. (2013). The Impact of Parenting Stress: A Meta-Analysis of Studies Comparing the Experience of Parenting Stress in Parents of Children with and without Autism Spectrum Disorder. Journal of Autism and Developmental Disorders, 43, 629-642. http://dx.doi.org/10.1007/s10803-012-1604-y

Marteleto, M. R. F., \& Pedromônico, M. R. M. (2005). Validity of Autism Behavior Checklist (ABC): Preliminary Study. Revista Brasileira de Psiquiatria, 27, 295-301.

McStay, R. L., Dissanayake, C., Scheeren, A., Koot, H. M., \& Begeer, S. (2013). Parenting Stress and Autism: The Role of Age, Autism Severity, Quality of Life and Problem Behaviour of Children and Adolescents with Autism. Autism, 18, 502-510.

Organização Mundial da Saúde (OMS) (2000). Classificação Internacional de Doenças CID-10. Revisão (8a ed.) (Tradução do Centro Colaborador da OMS para Classificação de Doenças em Português). São Paulo: Editora Universidade de São Paulo.

Rivard, M., Terroux, M., Parent-Boursier, C., \& Mercier, C. (2014). Determinants of Stress in Parents of Children with Autism Spectrum Disorders. Journal of Autism and Developmental Disorders, 44, 1609-1620. http://dx.doi.org/10.1007/s10803-013-2028-z

Schmidt, C., \& Bosa, C. (2003). A investigação do impacto do autismo na família: Revisão crítica da literatura e proposta de um novo modelo. Interação em Psicologia, 7, 111-120. http://dx.doi.org/10.5380/psi.v7i2.3229

Segeren, L. (2015) Correlação entre a oralidade de crianças com distúrbios do espectro do autismo e o nível de estresse de seus pais. Dissertação. São Paulo: Faculdade de Medicina da Universidade de São Paulo.

Segeren, L., \& Françozo, M. F. C. (2014). As vivências de mães de jovens autistas. Psicologia em Estudo, 19, 39-46. http://dx.doi.org/10.1590/1413-7372189590004

Sivberg, B. (2002). Family System and Coping Behaviours: A Comparison between Parents of Children with Autistic Spectrum Disorders and Parents with Non-Autistic Children. Autism, 6, 397-409. http://dx.doi.org/10.1177/1362361302006004006

Sperry, L. A., \& Symons, F. J. (2003). Maternal Judgments of Intentionality in Young Children with Autism: The Effects of Diagnostic Information and Stereotyped Behavior. Journal of Autism and Developmental Disorders, 33, 281-287.

http://dx.doi.org/10.1023/A:1024454517263

Tamanaha, A. C., Marteleto, M. R. F., \& Perissinoto, J. (2014). A interferência do status de linguagem expressiva na pontuação do Autism Behavior Checklist em autistas verbais e não verbais. Audiology, Communication Research [Serial on the Internet], 19, 167-170. 
Submit or recommend next manuscript to SCIRP and we will provide best service for you:

Accepting pre-submission inquiries through Email, Facebook, LinkedIn, Twitter, etc. A wide selection of journals (inclusive of 9 subjects, more than 200 journals)

Providing 24-hour high-quality service

User-friendly online submission system

Fair and swift peer-review system

Efficient typesetting and proofreading procedure

Display of the result of downloads and visits, as well as the number of cited articles

Maximum dissemination of your research work

Submit your manuscript at: http://papersubmission.scirp.org/

Or contact psych@scirp.org 